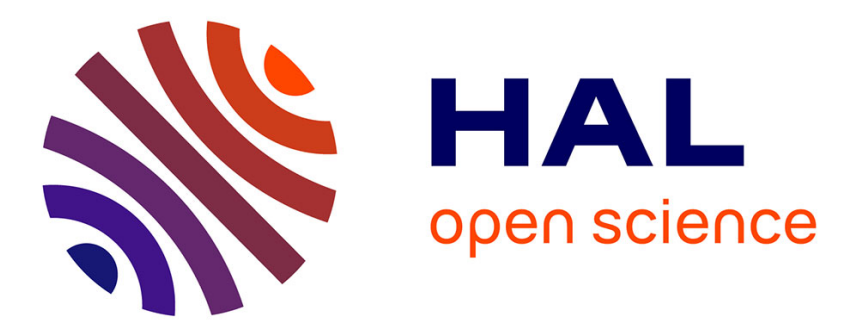

\title{
mTRIP, an Imaging Tool to Investigate Mitochondrial DNA Dynamics in Physiology and Disease at the Single-Cell Resolution
}

Laurent Chatre, Miria Ricchetti

\section{- To cite this version:}

Laurent Chatre, Miria Ricchetti. mTRIP, an Imaging Tool to Investigate Mitochondrial DNA Dynamics in Physiology and Disease at the Single-Cell Resolution. Methods in Molecular Biology, 2021, 2275, pp.247-263. 10.1007/978-1-0716-1262-0_15 . hal-03267686

HAL Id: hal-03267686

https://hal-normandie-univ.archives-ouvertes.fr/hal-03267686

Submitted on 22 Jun 2021

HAL is a multi-disciplinary open access archive for the deposit and dissemination of scientific research documents, whether they are published or not. The documents may come from teaching and research institutions in France or abroad, or from public or private research centers.
L'archive ouverte pluridisciplinaire HAL, est destinée au dépôt et à la diffusion de documents scientifiques de niveau recherche, publiés ou non, émanant des établissements d'enseignement et de recherche français ou étrangers, des laboratoires publics ou privés. 


\section{mTRIP, an Imaging Tool to \\ Investigate Mitochondrial DNA \\ Dynamics in Physiology and Disease at the Single-Cell Resolution}

Laurent Chatre 1,2

Email chatre@cyceron.fr

Miria Ricchetti 1 四

Emailmiria.ricchetti@pasteur.fr

1 Institut Pasteur, Stem Cells and Development, Department of Developmental and Stem Cell Biology, CNRS UMR3738 Team "Stability of Nuclear and Mitochondrial DNA", Paris, France

2 Present Address: Normandie Université, UNICAEN, CEA, CNRS, ISTCT/CERVOxy group, GIP Cyceron, Caen, France

\section{Abstract}

Mitochondrial physiology and metabolism are closely linked to replication and transcription of mitochondrial DNA (mtDNA). However, the characterization of mtDNA processing is poorly defined at the single-cell level. We developed mTRIP (mitochondrial Transcription and Replication Imaging Protocol), an imaging approach based on modified fluorescence in situ hybridization (FISH), which simultaneously reveals mitochondrial structures committed to mtDNA initiation of replication as well as the mitochondrial RNA (mtRNA) content at the single-cell level in human cells. Also specific RNA regions, rather than global RNA, can be tracked with mTRIP. In addition, mTRIP can be coupled to immunofluorescence for in situ protein tracking, or to MitoTracker, thereby allowing for simultaneous labeling of mtDNA, mtRNA, and proteins or mitochondria, respectively. Altogether, qualitative and quantitative alterations of the 
dynamics of mtDNA processing are detected by mTRIP in human cells undergoing physiological changes, as well as stress and dysfunction. mTRIP helped elucidating mtDNA processing alterations in cancer cells, and has a potential for diagnostic of mitochondrial diseases.

AQ1

\section{Key words}

Mitochondrial DNA

FISH

Imaging

mTRIP

Mitochondrial disease

Transcription

DNA replication

Single-cell

\section{Introduction}

Mitochondria are highly dynamic organelles that can fuse and divide to produce a variety of morphologies ranging from individual entities to interconnected tubular networks, which are functional to cell growth, cell physiology, and disease $[1,2]$. In eukaryotes, mitochondria play a central role in the energy metabolism that is regulated by the nuclear genome as well as the organelle genome. In mammals, individual mitochondria carry multiple copies of double-stranded circular mtDNA, packed into nucleoids structures and autonomously replicated and transcribed [3, 4]. The human mtDNA is a $16.5 \mathrm{kbp}$ molecule coding for two ribosomal RNAs, 22 transfer RNAs, and 13 protein-coding genes that are transcribed into polycistronic precursor RNAs and then processed to mature mRNAs, rRNAs, and tRNAs ([5]) (Fig. 1). The dynamics of mtDNA replication are still debated, and distinct models are proposed ([6-8], for reviews see [9-11]). Nevertheless, in these models initiation of replication takes place at the $\mathrm{O}_{\mathrm{H}}$ origin, and the nascent heavy $(\mathrm{H})$ strand may subsequently pause about 700 nucleotides downstream generating the 7S DNA, which produces a characteristic triple displacement loop or D-loop [12]. mtDNA replication and transcription have been extensively characterized by biochemical approaches, which assess values within large cell populations. In addition, superresolution imaging recently revealed, at the 
single cell level, that mtDNA replication occurs only in a subset of nucleoids $[13,14]$. These findings underscore the urgency of combined protein and DNA analysis of mitochondrial substructures. However, classic FISH procedures may damage protein epitopes and are therefore not suitable also for immunofluorescence analysis, thereby limiting the simultaneous track of mitochondrial nucleic acids and proteins.

\section{Fig. 1}

Schematic representation of the human mitochondrial DNA and probes used in mTRIP. The $\mathrm{H}$ (heavy) and light (L) strands of the mitochondrial genome are indicated in the external and inner circle, respectively, with the position and name of single genes within. tRNA genes are indicated with a black dot and the corresponding letter. All genes are located on the $\mathrm{H}$-strand, with the exception of ND6 and several tRNAs, located on the L-strand. Magnification of the D-loop region (which contains H-strand origin of replication $\left(\mathrm{O}_{\mathrm{H}}\right)$ and promoters of both $\mathrm{H}$ (PH1 and $\left.\mathrm{PH} 2\right)$ and $\mathrm{L}$ (PL) strands) is shown on top. Blue arrows indicate the direction of DNA replication from $\mathrm{O}_{\mathrm{H}}$ and $\mathrm{O}_{\mathrm{L}}$. The position of probe mREP and probes 1, 6, and 11 is indicated with a red box. mTRANS is a mix of probes 1,6 , and 11, which targets rRNA as well as several coding genes and tRNA on both strands 


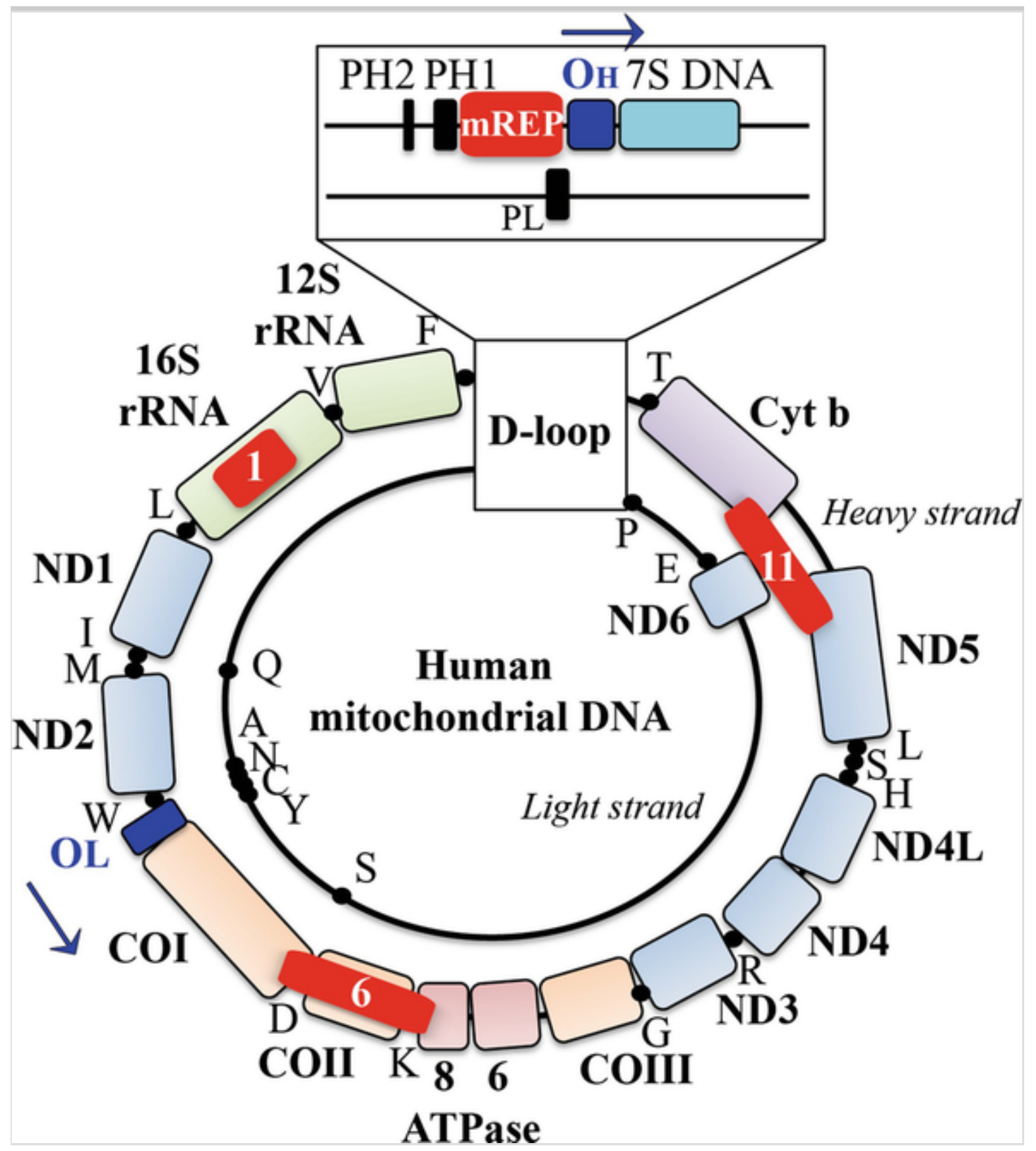

mTRIP, a novel imaging protocol based on modified FISH, identifies mitochondrial entities engaged in the mtDNA initiation of replication, and can simultaneously reveal the mitochondrial RNA (mtRNA) content in single human cells. Moreover mTRIP can be coupled to immunofluorescence, making possible the combined detection of mtDNA initiation of replication, mtRNA content, and proteins of choice in single human cells [15] (Fig. 2). MtDNA initiation of replication is identified by the mREP probe, which targets a specific DNA region located upstream of the replication origin $\mathrm{O}_{\mathrm{H}}$ and within in the regulatory D-loop. Probe mREP recognizes only DNA in an open structure; therefore, the double- 
stranded mitochondrial genome that is not engaged in replication initiation is not detected by mREP. mTRANS, a mix of three DNA probes located on different regions of the mitochondrial genome, detects specific mtRNAs which are considered representative of global mtRNA levels (Fig. 1).

\section{Fig. 2}

Scheme of mTRIP labeling. Summary and chronology of steps of mTRIP labeling described in detail in this document. After labeling, 3D confocal acquisition and the subsequent treatment of acquisitions are shown. 3D acquisition is necessary for fluorescence quantification of the entire cell volume, but also 2D acquisition of a single plan (and thereby fluorescence quantification of this single plan) can be performed (not shown here) 


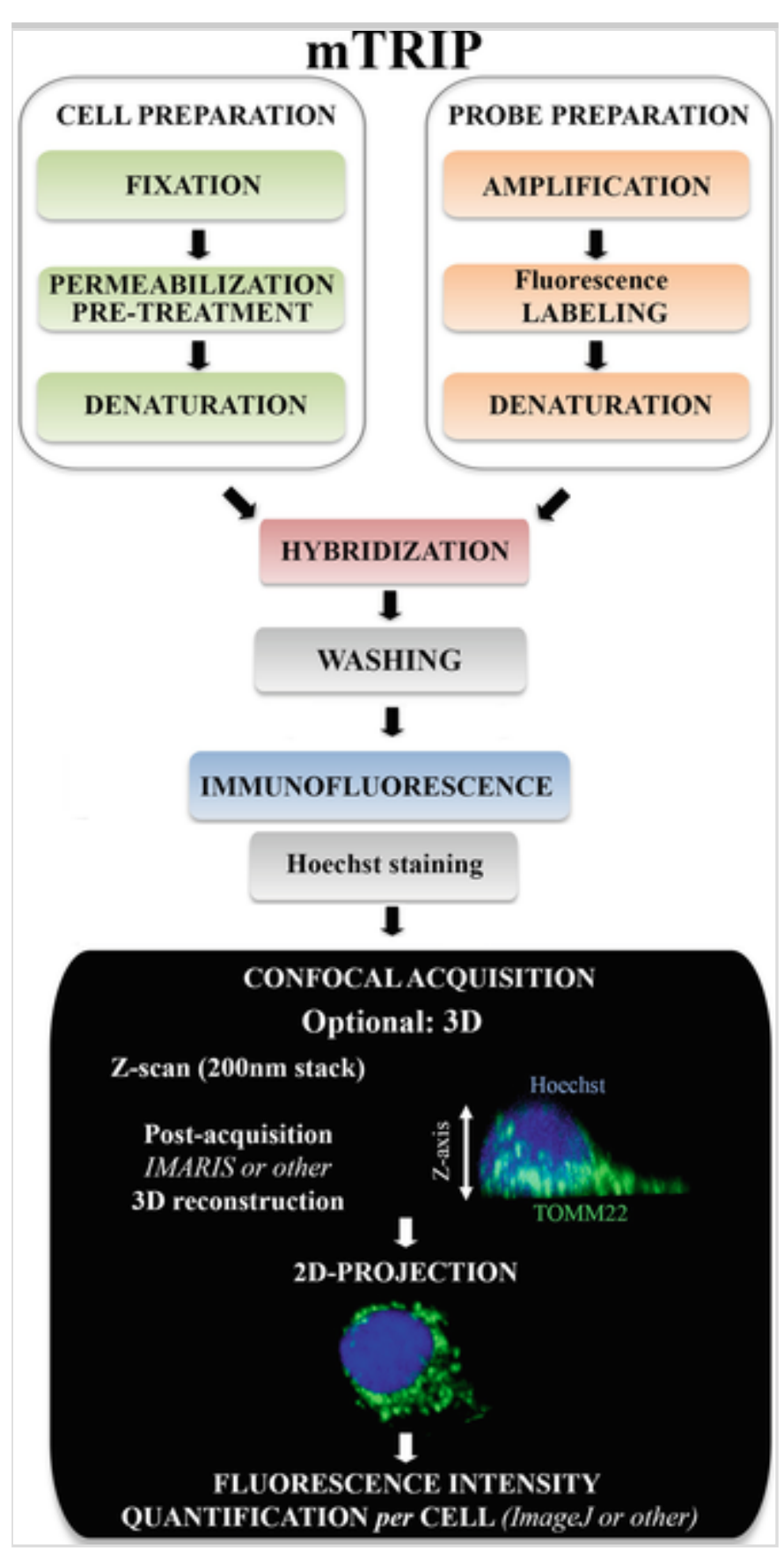

We generally associate mTRIP analysis of mitochondrial nucleic acids with immunofluorescence of a mitochondrial outer membrane protein (TOM22 or TOMM22) to identify the mitochondrial network. These labeling allow for the detection and quantification of at least three classes of mitochondrial subpopulations: (1) replication initiation active and transcript-positive (Ia-Tp); (2) replication initiation silent and transcriptpositive (Is-Tp); and (3) replication initiation silent and transcriptnegative (Is-Tn) [15], revealing that individual mitochondria are strongly heterogeneous within human cells (Fig. 3a-d). This heterogeneity is functional to physiological changes, as during the cell cycle [16], and can 
be also affected during stress and disease [15]. mTRIP can be also associated with MitoTracker analysis, which detects mitochondria in living cells, based on its binding to thiol groups present in the organelle (Fig. 3e-h). Other probes than mREP and mTRANS can be produced to target specific regions of interest in the mitochondrial genome (see Ref. 15). For instance, mTRIP labeling with either a LSP (Light Strand Promoter)-specific probe or an ND6 (NADH-ubiquinone oxidoreductase chain 6)-specific probe was combined with immunostaining of the mitochondrial transcription factor and DNA binding protein TFAM for colocalization experiments. ND6 is the only gene located in the L-strand of the mitochondrial genome (see Fig. 1), and is a component of the respiratory complex I. mTRIP contributed to show that the mitochondrial fraction of the protooncogene MDM2 directly impacts on TFAM binding to the LSP, thereby affecting ND6 transcription $\theta$ and thereby the respiratory complex I function in cancer cells [17]. Described and novel mTRIP probes, combined with a variety of immunofluorescence and mitochondrial markers (Fig. 4) should help decipher mtDNA dynamics and their impact under physiological changes, including stress, and in disease.

\section{Fig. 3}

mTRIP colabeling with either immunofluorescence mitochondrial proteins or Mitotracker. Panels a-d: Colabeling of TOMM22 immunofluorescence (green, panel a), mTRANS (red, panel b), and mREP (blue, panel c) probes, shows mitochondrial initiation of replication, transcription, and mitochondrial network, respectively. In merge, mREP essentially colocalizes with mTRANS (purple; arrow; Ia-Tp, replication Initiation active and Transcript positive), and independent mTRANS labeling (orange; arrow; Is-Tp, replication Initiation silent and Transcript active), as well as replication Initiation silent and Transcript negative mitochondrial structures (green; arrow, Is-Tn) are also observed. Panels (e-h) Colabeling of MitoTracker Deep Red (purple; panel e), mTRANS (green; panel f), mREP (red, panel $\mathbf{g}$ ), and merge (panel $\mathbf{h}$, which was also counterstained with Hoechst, blue, for nucleus detection). MitoTracker labeling results in a more diffused signal than immunofluorescence and mTRIP, therefore colocalization with other markers appears less defined in panel $\mathbf{h}$ than in panel d. Ia-Tp, Is-Tp, and Is-Tn mitochondrial structures are detected also with this colabeling (presence or absence of labeling in panels $\mathbf{e}-\mathbf{g}$ is shown 
rather than in merge, because of the limited resolution of the combined fluorescence signal by visual detection). Scale bars $=10 \mu \mathrm{m}$
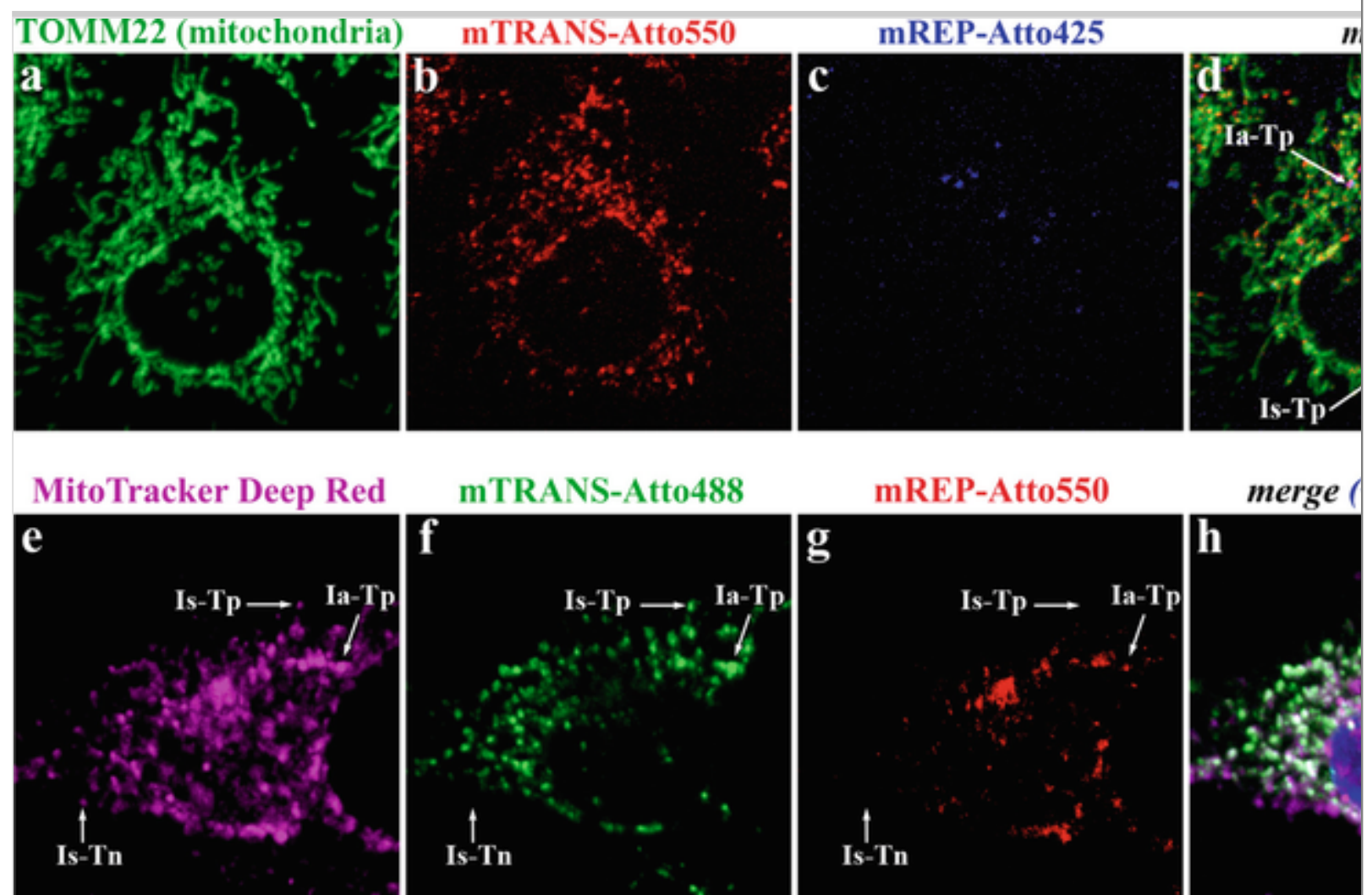

merge (

Fig. 4

Single-cell analysis with mTRIP alone and in combination with other approaches. The readouts of distinct mTRIP probes alone and in combination with immunofluorescence or MitoTracker labeling are indicated 


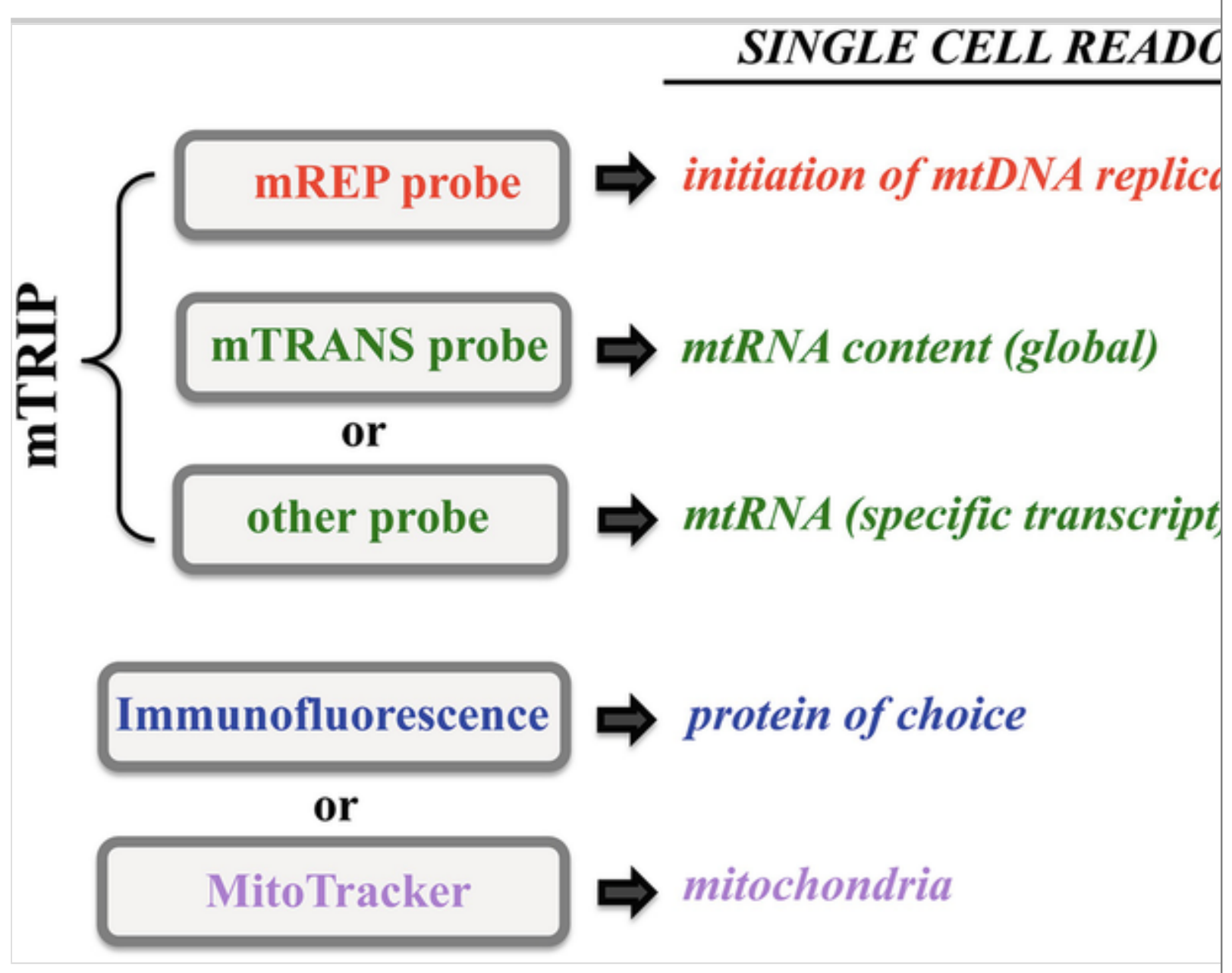

Notably, the mREP and mTRANS probes alone can act as markers of functional mtDNA processing. The investigation of functional mtDNA processing in single cells has relevance beyond classical mitochondrial activity (oxidative phosphorylation). For instance, mTRIP labeling with these two probes contributed to demonstrate that mtDNA acquired from the host mouse by mtDNA-depleted grafted cancer cells was not only present but also fully functional in individual cells a few days after grafting [18]. This work demonstrated that acquisition and processing of host mtDNA, and thereby restoration of mitochondrial respiration, are essential for tumorigenesis, although not for ATP production but rather pyrimidine biosynthesis through dihydroorotate dehydrogenase (DHODH) reactivation [18]. In another study, mTRIP detection of mtDNA initiation of replication using the mREP probe helped understanding the dynamics of mtDNA synthesis/depletion. Indeed, a novel function of the endonuclease $\mathrm{G}$ (EndoG) both as a stimulator of mtDNA replication initiation and mtDNA depletion was identified [19, 20]. Further In this study, experiments that included the mTRANS probe contributed to 
demonstrate that removal of damaged mtDNA by EndoG is compensated by mtDNA replication to maintain mtDNA transcription and mitochondria homeostasis $[19,20]$.

mTRIP is therefore a versatile and powerful tool to investigate single cell dynamics of mitochondrial DNA processing in physiology and disease.

\section{Materials}

Prepare all solutions using ultrapure water when needed. Follow all waste disposal regulations when disposing of waste materials.

\subsection{Probe Preparation and Labeling}

1. Lysis buffer to extract total genomic DNA: $0.2 \%$ SDS, $5 \mathrm{mM}$ EDTA, $0.2 \mathrm{mg} / \mathrm{ml}$ Proteinase $\mathrm{K}$ in $1 \times$ phosphate buffered saline (PBS) buffer.

2. Sodium acetate $3 \mathrm{M}, \mathrm{pH} 5.2$, cold ultrapure isopropanol and ultrapure water.

3. Taq DNA polymerase (we recommend LA Taq DNA polymerase TaKaRa).

4. Primers for PCR amplification of the mREP probe from total genomic DNA:

Coordinates of all primers are according to NC_012920 GenBank.

mREP (98 nucleotides, nt): coordinates 446-544.

Forward 5'-ACATTATTTTCCCCTCCC-3'.

Reverse 5'-GGGGTATGGGGTTAGCAG-3'.

5. Primers for PCR amplification of the mTRANS probe from total genomic DNA:

mTRANS is an equimolar mix of three DNA probes: probe 1 , 
probe 6 , and probe 11 .

Primers for PCR amplification of DNA probe 1 (961 nt):

Forward 5'-ACCAGACGAGCTACCTAAGAACAG-3'.

Reverse 5'-CTGGTGAAGTCTTAGCATGT-3'.

Primers for PCR amplification of DNA probe $6(1118 \mathrm{nt})$ :

Forward 5'-CTACCACACATTCGAAGAACC-3'.

Reverse 5'-CGTTCATTTTGGTTCTCAGGG-3'.

Primers for PCR amplification of DNA probe 11 (1420 nt):

Forward 5'-CATACCTCTCACTTCAACCTC-3'.

Reverse 5'-TGAGCCGAAGTTTCATCATGC-3'.

6. PCR products cleanup system kit (see Note 1).

7. Labeling of purified mREP and mTRANS PCR products. It is strongly recommended to label the DNA probes by Nicktranslation using Atto425 or Atto488 or Atto550 or Atto647 NT Labeling Kit (JenaBioscience) (see Note 2).

Labeled and purified mREP and mTRANS probes must be aliquoted and stored at $-20{ }^{\circ} \mathrm{C}$ in the dark.

\subsection{Cell Treatment}

1. Tissue culture plates 6-well (12-well or 24-well plates are reasonable alternatives for culture of rare primary cells or slow growing cells).

2. Microscope glass coverslips $18 \mathrm{~mm}$ diameter.

3. $2 \%$ Paraformaldehyde (PFA) in $1 \times$ PBS (mix $5 \mathrm{ml}$ of $16 \%$ PFA with $35 \mathrm{ml}$ of $1 \times$ PBS). 
4. $2 \%$ PFA can be stored at $4{ }^{\circ} \mathrm{C}$ for a couple of weeks.

5. Permeabilization buffer: $0.5 \%$ Triton $X-100$ in $1 \times \operatorname{PBS}(\operatorname{mix} 50 \mu 1$ of $100 \%$ Triton X-100 with $9550 \mu 11 \times$ PBS).

6. $20 \times$ saline sodium-citrate (SSC) buffer: $150 \mathrm{mM} \mathrm{NaCl}, 15 \mathrm{mM}$ $\mathrm{Na}_{3}$ Citrate $\times 2 \mathrm{H}_{2} \mathrm{O}, \mathrm{pH}$ 7.0). For SSC preparation, dissolve $175.3 \mathrm{~g}$ of $\mathrm{NaCl}$ and $88.2 \mathrm{~g}$ of sodium citrate in $800 \mathrm{ml}$ of ultrapure water. Adjust the $\mathrm{pH}$ to 7.0 with $14 \mathrm{~N}$ solution of $\mathrm{HCl}$. Adjust the volume to 11 with additional ultrapure water. Sterilize by autoclaving. Store at room temperature up to 6 months.

7. Pretreatment buffer for permeabilized cells: $50 \%$ formamide $-2 \times$ SSC in $1 \times$ PBS. Store the solution at room temperature up to 6 months in the dark.

8. Denaturation buffer for permeabilized cells: $70 \%$ formamide $-2 \times$ SSC in $1 \times$ PBS.

Store the solution at room temperature up to 6 months in the dark.

\section{3. mTRIP Hybridization}

1. Parafilm.

2. Hybridization buffer: $10 \%$ dextran sulfate $-50 \%$ formamide $-2 \times$ SSC in $1 \times$ PBS).

Store the solution at room temperature up to 6 months in the dark (see Note 3).

3. $100 \mathrm{ng} / \mu 1 \mathrm{salmon}$ sperm DNA: dilute stock salmon sperm DNA with $1 \times$ PBS.

Store the solution at $-20{ }^{\circ} \mathrm{C}$.

4. Washing buffer A: $2 \times \mathrm{SSC}$ in $1 \times$ PBS.

5. Washing buffer B: $1 \times$ SSC in $1 \times$ PBS. 
6. Washing buffer C: $0.1 \times$ SSC in $1 \times$ PBS.

\section{4. mTRIP Coupled to Immunofluorescence}

1. Parafilm.

2. Blocking buffer: $5 \%$ bovine serum albumin (BSA) in $1 \times$ PBS. The solution can be stored at $4{ }^{\circ} \mathrm{C}$ several weeks (see Note 4).

3. Primary antibody (see Note 5): we recommend the use of unconjugated rabbit polyclonal anti-TOMM22 to label mitochondria.

4. Fluorescence-conjugated secondary antibody (see Note 6): we recommend the use of Cy5 (or similar) conjugated goat secondary anti-rabbit antibody.

5. Hoechst 33342.

\section{5. mTRIP Coupled to MitoTracker ${ }^{\circledR}$}

MitoTracker ${ }^{\circledR}$ Probes, Invitrogen. Select a MitoTracker probe with appropriate spectral characteristics for successive labeling with mTRIP. Here we used MitoTracker ${ }^{\circledR}$ Deep Red (655 nm).

\subsection{Imaging Equipment}

1. Confocal microscope.

2. Optional for 3D imaging: 3D-reconstruction imaging software.

3. Quantification-imaging software such as Image J.

\section{Methods}

mTRIP principles are summarized in Fig. 2 .

\subsection{Extraction of Total Genomic DNA}


It is strongly recommended to use primary cells such as IMR90 at early passages (and not cancer-derived or immortalized cell lines) (see Note 7).

1. Add $200 \mu 1$ of fresh lysis buffer to the cell pellet at $50{ }^{\circ} \mathrm{C}$ for 3 hours (h).

2. Incubate at $50{ }^{\circ} \mathrm{C}$ for $3 \mathrm{~h}$.

3. Add $20 \mu \mathrm{l}$ of sodium acetate $3 \mathrm{M}, \mathrm{pH} 5.2$.

4. Add $200 \mu 1$ of cold ultrapure isopropanol.

5. Incubate at $-20^{\circ} \mathrm{C}$ for $15 \mathrm{~min}$.

6. Centrifuge at $16,100 \times g$ at $4{ }^{\circ} \mathrm{C}$ for $30 \mathrm{~min}$.

7. Carefully discard the supernatant.

8. Add $500 \mu 1$ of $70 \%$ ethanol.

9. Centrifuge at $16,100 \times g$ at $4{ }^{\circ} \mathrm{C}$ for $5 \mathrm{~min}$.

10. Carefully discard the supernatant.

11. Dry the DNA pellet for 5 min at room temperature. The pellet should be transparent after drying.

12. Resuspend the DNA pellet in $100 \mu$ of ultrapure water.

13. Incubate at $4{ }^{\circ} \mathrm{C}$ overnight.

14. Quantify the total genomic DNA. Dilute in ultrapure water, if needed.

15. Storage: $-20^{\circ} \mathrm{C}$.

\subsection{Preparation and Labeling of the DNA Probe}

1. Amplify the mREP probe by PCR using at least $100 \mathrm{ng} / \mu \mathrm{l}$ of total genomic DNA and LA Taq DNA polymerase (Recommendation: annealing temperature: $56^{\circ} \mathrm{C}$; extension: $68^{\circ} \mathrm{C}$ ). 
2. Amplify the mTRANS component probe 1 by PCR using at least $100 \mathrm{ng} / \mu \mathrm{l}$ of total genomic DNA and LA Taq DNA polymerase (recommendation: annealing temperature: $56{ }^{\circ} \mathrm{C}$; extension: $\left.68^{\circ} \mathrm{C}\right)$.

3. Amplify the mTRANS component probe 6 by PCR using at least $100 \mathrm{ng} / \mu \mathrm{l}$ of total genomic DNA and LA Taq DNA polymerase (recommendation: annealing temperature: $56{ }^{\circ} \mathrm{C}$; extension: $\left.68^{\circ} \mathrm{C}\right)$.

4. Amplify the mTRANS component probe 11 by PCR using at least $100 \mathrm{ng} / \mu \mathrm{l}$ of total genomic DNA and LA Taq DNA polymerase (recommendation: annealing temperature: $56{ }^{\circ} \mathrm{C}$; extension: $\left.68^{\circ} \mathrm{C}\right)$.

5. Purify the PCR products using 2\% agarose electrophoresis gel and conventional PCR products cleanup kit.

6. Estimate the amount of the purified PCR product. It is essential to get $1 \mu \mathrm{g}$ of PCR product at a concentration of $75 \mathrm{ng} / \boldsymbol{\mu l}$ or higher. If this amount of DNA product is not reached, one can concentrate the DNA by sodium acetate and isopropanol precipitation, then resuspend in the appropriate volume of ultrapure water to reach the required concentration. Note that precipitation of highly diluted DNA is not recommended at it may result in salt concentration higher than necessary, in spite of intense washing.

Be careful as the following steps are dedicated to $D N A$ probes fluorescent labeling by nick translation and are crucial for mTRIP. Consider that no other technique of DNA labeling than nick translation has been tested in this context.

7. Choose the fluorescence label for mREP and mTRANS DNA probes (see Note 8). If mTRIP is coupled to immunofluorescence and Hoechst 33342, resulting in four-color channels, the recommended choice is mREP labeled with Atto550 NT kit, mTRANS labeled with Atto488 NT kit, immunofluorescence with a Cy5-conjugated secondary antibody, and Hoechst. 
8. Preparation of the mREP DNA probe:

(a) Resuspend $1 \mu \mathrm{g}$ of pure PCR product in a maximum volume of $14 \mu \mathrm{l}$ in a $0.2 \mathrm{ml}$ thin-wall 8 -tube strip with caps for regular thermal cycler (PCR machine).

If the volume is smaller, adjust to $14 \mu 1$ with PCR-grade water from the kit.

9. Preparation of the mTRANS DNA mix probes.

(a) Mix $333 \mathrm{ng}$ of mTRANS probe 1, $333 \mathrm{ng}$ of mTRANS probe 6 , and $333 \mathrm{ng}$ of mTRANS probe 11 (equimolar amounts of the three probes) for a final amount of $1 \mu \mathrm{g}$ of DNA mix, in maximum volume of $14 \mu \mathrm{l}$ in a $0.2 \mathrm{ml}$ thinwall 8-tube strip with caps for regular thermal cycler (PCR machine).

If the volume is smaller adjust to $14 \mu \mathrm{l}$ with PCR-grade water from the kit.

\section{The following steps are identical for mREP and mTRANS fluorescence labeling.}

10. Gently mix $14 \mu 1$ of template DNA with $2 \mu 1$ of $10 \times$ NT labeling buffer on ice.

11. Add $2 \mu 1$ of Atto488 or Atto550 NT labeling mix.

12. Add $2 \mu 1$ of $10 \times$ Enzyme mix.

13. Ensure sample homogeneity by gently mixing.

14. Incubate the mix at $15^{\circ} \mathrm{C}$ for $90 \mathrm{~min}$, for example in a regular thermal cycler, in the dark.

15. Add $5 \mu 1$ of NT Kit Stop buffer to stop the reaction.

16. Transfer the reaction mixture in $1.5 \mathrm{ml}$ Eppendorf tube. 
17. Add $2 \mu \mathrm{l}$ of $3 \mathrm{M} \mathrm{pH} 5.2$ sodium acetate.

18. Add $14 \mu \mathrm{l}$ of ultrapure cold isopropanol.

19. Gently mix the sample.

20. Incubate at $-20{ }^{\circ} \mathrm{C}$ for $15 \mathrm{~min}$ in the dark.

21. Centrifuge at $16,100 \times g$ at $4{ }^{\circ} \mathrm{C}$ for $30 \mathrm{~min}$.

22. Discard the supernatant.

23. Add $500 \mu 1$ of $70 \%$ ethanol.

24. Centrifuge at $16,100 \times g$ at $4{ }^{\circ} \mathrm{C}$ for $5 \mathrm{~min}$.

25. Discard the supernatant.

26. Add $500 \mu 1$ of $70 \%$ Ethanol.

27. Centrifuge at $16,100 \times g$ at $4{ }^{\circ} \mathrm{C}$ for $5 \mathrm{~min}$.

28. Discard the supernatant.

29. Resuspend the fluorescence-labeled DNA probe in $50 \mu 1$ of ultrapure water to get a final concentration of $20 \mathrm{ng} / \mu 1$.

30. Store the labeled DNA probe at $-20{ }^{\circ} \mathrm{C}$ in the dark.

\subsection{Prehybridization of the DNA Probe}

To reduce bench timing, the steps in this section can be done in parallel with the steps of Subheading 3.4.

AQ2

1. Choice 1: ONE probe, preparation of the reaction mixture (in a $1.5 \mathrm{ml}$ tube):

If only one probe (e.g., mREP or mTRANS) is used, the reaction mix is done in a final volume of $25 \mu 1$ per coverslip. Gently mix 
$2 \mu \mathrm{l}$ of $20 \mathrm{ng} / \mu \mathrm{l}$ of fluorescent DNA probe (40 ng DNA probe are used per coverslip at a final concentration of $1.6 \mathrm{ng} / \mu \mathrm{l})$ with $4 \mu \mathrm{l}$ of $100 \mathrm{ng} / \mu 1$ salmon sperm DNA (400 ng of salmon sperm DNA are used for $40 \mathrm{ng}$ of DNA probe, and per coverslip) and $19 \mu \mathrm{l}$ of hybridization buffer.

2. Choice 2: TWO probes, preparation of the reaction mixture (in a $1.5 \mathrm{ml}$ tube):

If two probes (mREP and mTRANS) are used, the reaction mix is done in a final volume $25 \mu \mathrm{l}$ per coverslip. Gently mix $2 \mu 1$ of $20 \mathrm{ng} / \mu \mathrm{l}$ fluorescent mREP probe (40 $\mathrm{ng}$ of DNA probe are used per coverslip; final concentration $1.6 \mathrm{ng} / \mu \mathrm{l})$ and $2 \mu \mathrm{lof} 20 \mathrm{ng} / \mu \mathrm{l}$ fluorescent mTRANS probe (40 ng DNA probe are used per coverslip; final concentration $1.6 \mathrm{ng} / \mu \mathrm{l}$ ) with $8 \mu \mathrm{lof} 100 \mathrm{ng} / \mu \mathrm{l}$ of salmon sperm DNA (800 ng of salmon sperm DNA are used for $2 \times$ $40 \mathrm{ng}$ of DNA probes and per cove slip) and $13 \mu \mathrm{l}$ of hybridization buffer.

3. Denaturation: incubate the reaction mixture at $80{ }^{\circ} \mathrm{C}$ for $10 \mathrm{~min}$ in the dark.

4. Precooling step: transfer the denatured reaction mixture containing tube at $37^{\circ} \mathrm{C}$ for at least $30 \mathrm{~min}$ in the dark. This time can be extended to a maximum of $1 \mathrm{~h}$ at $37{ }^{\circ} \mathrm{C}$ in the dark. This step helps lowering unspecific binding of salmon sperm DNA versus specific binding of DNA probes. Keep denatured reaction mixture under these conditions until the end of Subheading 3.4.

\subsection{Preparation of Cells on Coverslip}

1. Culture cells under appropriate culture conditions in (6-wells or 12-wells) culture plates containing a clean coverslip at the bottom of each well. Ideally cells should be grown at about 50-60\% confluence to avoid plans with packed cell during microscope analysis.

If mTRIP is coupled to MitoTracker labeling, incubate live cells with MitoTracker ${ }^{\circledR}$ (e.g., MitoTracker ${ }^{\circledR}$ Deep Red) for $1 \mathrm{~h}$ in 
appropriate culture conditions (see Note 9).

2. Discard the culture medium.

3. Wash cells once with $1 \times$ PBS.

4. Add 2\% PFA at room temperature.

5. Incubate for $20 \mathrm{~min}$ at room temperature.

6. Discard PFA.

7. Wash $2 \times$ with $1 \times$ PBS. At this step, PFA-fixed cells can be stored in $1 \times$ PBS for several weeks at $4{ }^{\circ} \mathrm{C}$.

8. Discard PBS from the coverslip.

9. Permeabilize cells with $0.5 \%$ Triton $\mathrm{X}-100$ in $1 \times \mathrm{PBS}$ for $5 \mathrm{~min}$ at $4{ }^{\circ} \mathrm{C}$.

10. Discard the Triton X-100.

11. Wash $4 \times$ with $1 \times$ PBS.

OPTIONAL: if required, at this step permeabilized cells can be incubated with specific nucleases for the time recommended by the manufacturer (generally $1 \mathrm{~h}$ at $37^{\circ} \mathrm{C}$ ). After incubation, wash $4 \times$ with $1 \times$ PBS (see Note 10 ).

12. Discard PBS.

13. Pretreat the permeabilized cells by adding pretreatment buffer ( $50 \%$ formamide $-2 \times$ SSC in $1 \times$ PBS).

14. Incubate at room temperature for $30 \mathrm{~min}$.

15. Discard the pretreatment buffer.

16. Add $70 \%$ formamide $-2 \times \mathrm{SSC}$ in $1 \times \mathrm{PBS}$.

17. Put the 6-well culture plate (with, at the bottom of each well, a 
coverslip with pretreated permeabilized cells) on the top of a metal block heater at $75{ }^{\circ} \mathrm{C}$ for $5 \mathrm{~min}$ to denature the sample.

18. Immediately transfer the 6 -well culture plate on ice $\left(4^{\circ} \mathrm{C}\right)$ and keep on ice at least $1 \mathrm{~min}$ and not longer than $10 \mathrm{~min}$ (see Note 11).

\section{5. mTRIP Hybridization}

1. Put a $25 \mu 1$ drop of denatured and precooled reaction mixture which contains DNA probe(s) on an appropriate surface of Parafilm (at least $3.6 \times 3.6 \mathrm{~cm}$ for $18 \mathrm{~mm}$ diameter coverslip). For multiple labeling, use a single surface of Parafilm with enough room for multiple and well separated drops.

2. Put the coverslip upside down, with the face containing cells (samples previously undergone denaturation) directly on the drop.

3. Incubate at $37^{\circ} \mathrm{C}$ for $15 \mathrm{~h}$ either at the top of a heating metal block in the dark (cover with plastic top to set dark) or on a humid chamber at $37{ }^{\circ} \mathrm{C}$ in the dark.

\section{6. mTRIP Washing}

1. After $15 \mathrm{~h}$ incubation, remove the coverslip from Parafilm and put it back into a clean cell culture plate (6-well plate).

The following steps must be performed in the dark:

2. Wash $2 \times$ with $2 \times \mathrm{SSC}$ in $1 \times \mathrm{PBS}$ for 2 min at room temperature (RT) with gentle shaking.

3. Wash $2 \times$ with $1 \times \mathrm{SSC}$ in $1 \times \mathrm{PBS}$ for 2 min at RT with gentle shaking.

4. Wash $2 \times$ with $0.1 \times \mathrm{SSC}$ in $1 \times \mathrm{PBS}$ for 2 min at RT with gentle shaking.

5. Wash $2 \times$ with $1 \times$ PBS for 2 min at RT with gentle shaking. 
At this point, either label the sample by immunofluorescence, and in this case go to Subheading 3.7 (mTRIP coupled to immunofluorescence) or do not label the sample by immunofluorescence (this is also the case for MitoTracker labeling), and in this case:

6. Incubate the coverslip for $1 \mathrm{~h}$ in the dark with $10 \mu \mathrm{g} / \mathrm{ml}$ Hoechst 33342 in $1 \times$ PBS.

7. Wash $5 \times$ with $1 \times$ PBS.

8. Mount the coverslip on a clean and dry glass slide using the favorite mounting buffer or a drop of $50 \%$ glycerol in $1 \times$ PBS.

9. Seal the slide with varnish and keep the mounted slide in a dark and clean box either at room temperature if confocal analysis is done the done the same day, or at $4{ }^{\circ} \mathrm{C}$ until confocal analysis is done (it is recommended to analyze the slide not later than 2 weeks from labeling).

\section{7. mTRIP Coupled to Immunofluorescence}

Follow the immunofluorescence (IF) protocol suggested below, (see Note 12).

1. Incubate the coverslip with $5 \%$ BSA in $1 \times \mathrm{PBS}$ at RT for $1 \mathrm{~h}$ in the dark.

2. Wash $2 \times$ in $1 \times$ PBS for 2 min at RT with gentle shaking.

3. Dilute the primary antibody (anti-TOMM22 (1:200), recommended for assessing the mitochondrial network) in $1 \%$ BSA and $1 \times$ PBS.

4. Put a $50 \mu 1$ drop of diluted primary antibody mix on an appropriate surface of Parafilm.

5. Put the coverslip upside down, with the face containing cells directly on the drop. 
6. Incubate at RT for $1 \mathrm{~h}$ in the dark. The incubation time depends on the primary antibody.

7. Wash $3 \times$ in $1 \times$ PBS for 2 min at RT with gentle shaking.

8. Dilute secondary antibody $(1: 1000)$ in $1 \%$ BSA and $1 \times$ PBS, and add $10 \mu \mathrm{g} / \mathrm{ml}$ of Hoechst 33342 .

9. Put a $50 \mu 1$ drop of diluted secondary antibody mix on an appropriate surface of Parafilm.

10. Put the coverslip upside down, with the face containing cells directly on the drop.

11. Incubate at RT for $1 \mathrm{~h}$ in the dark.

12. Wash $5 \times$ in $1 \times$ PBS for 2 min at RT with gentle shaking.

13. Mount the coverslip on a clean and dry slide using the favorite mounting buffer or a drop of $50 \%$ glycerol in $1 \times$ PBS.

14. Seal the slide with varnish and keep the mounted slide in a dark and clean box either at room temperature if confocal analysis is done the same day, or at $4{ }^{\circ} \mathrm{C}$ until confocal analysis is done (it is recommended to analyze the slide not later than 2 weeks from labeling).

\subsection{Imaging Acquisition and Fluorescence Intensity Quantification}

1. Acquisition for subsequent quantification is done with confocal microscope (see Note 13).

2. One can do either two-dimensional (2D) or three-dimensional (3D) acquisition. In the last case $3 \mathrm{D}$ reconstruction of the image should follow 3D acquisition.

3. With image format (.tiff) of the acquired image, one can quantify the fluorescence intensity per per cell using the Image J software. 
A 3D-reconstructed human cell stained by mTRIP is shown in Fig. 3 (panels $b, c, f, g$ ). The mTRIP procedure is covered by a patent application for commercial use (Note 14), which also includes tissues sections (Note 15).

\section{Notes}

\section{AQ3}

1. Wizard ${ }^{\circledR}$ SV Gel, PCR clean-Up system (Promega), and NucleoSpin ${ }^{\circledR}$ Extract II (Macherey-Nagel) worked well in our hands.

2. Labeling of DNA probes with other techniques than Nick Translation has not been tested. We do not exclude that other DNA probes labeling techniques are compatible with mTRIP.

3. It is strongly recommended to prepare the hybridization buffer several days (at least 2 days) before the experiment as dextran sulfate takes a long time to dissolve.

4. Alternative blocking buffers can also be used.

5. Unconjugated rabbit polyclonal anti-TOMM22 is used to illuminate the mitochondrial network. However, you can use other primary antibodies for detecting the mitochondrial network, or other cellular structures or proteins of interest.

6. The choice of the secondary antibody-conjugated fluorescence depends on the available spectra after exclusion of the fluorophore(s) used for DNA probes (mTRIP). All combinations compatible with available fluorophores and the equipment (fluorescence filters) of your microscope can be used.

7. Cancer and immortalized cell lines may have mutated and highly heteroplasmic mitochondrial genomes.

8. The fluorescence color of the DNA probes can be different from the ones used here, and for this, appropriate fluorophores must be selected. 
9. In this case, use mREP-Atto550 and mTRANS-Atto-488 for mTRIP labeling, and Hoechst.

10. Treatment with DNaseI (recommended $100 \mathrm{U} / \mathrm{ml}$ ) or RNaseA (recommended $100 \mu \mathrm{g} / \mathrm{ml}$ ) allows identification of the DNA and RNA components of the mTRIP signal. Treatment with RNaseH (recommended $100 \mathrm{U} / \mathrm{ml}$ ) allows identification of RNA/DNA structures, usually at replication origins and in transcription bubbles. For combined use of nucleases and the respective readouts on mitochondrial nucleic acids by mTRIP, see Ref. 15 .

11. Do not keep denatured samples at room temperature, as this condition will interfere with the hybridization step. Keep the samples always on ice until hybridization.

12. The favorite IF procedure, if different form the one described here, can alternatively be performed.

13. Reliable quantification requires fluorescence measurement of the cell volume. Cell surface (2D-acquisition) can also be acquired instead of cell volume, but the corresponding quantification will not measure the total cell fluorescence.

14. mTRIP tool is covered by patent applications: EP2500436 and WO2012123588 "Method, probe and kit for DNA in situ hybridization and use thereof."

15. mTRIP can be used with paraformaldehyde-fixed human cells and paraffin-embedded human tissue sections (method not described here).

\section{Acknowledgments}

This work was supported by Association Nationale contre le Cancer (ARC 4022 and SFI20111204038), PTR-Institut Pasteur (PTR217), DARRIInstitut Pasteur (projects P790319 and PasteurInnov 14/152), and Agence Nationale pour la Recherche (ANR 11BSV202502).

\section{References}


1. Chan DC (2020) Mitochondrial dynamics and its involvement in disease. Annu Rev Pathol 15:235-259

2. Tilokani L, Nagashima S, Paupe V, Prudent J (2018) Mitochondrial dynamics: overview of molecular mechanisms. Essays Biochem 62:341-360

3. Barshad G, Marom S, Cohen T, Mishmar D (2018) Mitochondrial DNA transcription and its regulation: An evolutionary perspective. Trends Genet 34:682-692

4. Farge G, Falkenberg M (2019) Organization of DNA in mammalian mitochondria. Int J Mol Sci 20:2770

5. Ojala D, Montoya J, Attardi G (1981) tRNA punctuation model of RNA processing in human mitochondria. Nature 290:470-474

6. Chang DD, Clayton DA (1985) Priming of human mitochondrial DNA replication occurs at the light-strand promoter. Proc Natl Acad Sci U S A $82: 351-355$

7. Clayton DA (1991) Replication and transcription of vertebrate mitochondrial DNA. Annu Rev Cell Biol 7:453-478

8. Holt IJ, Lorimer HE, Jacobs HT (2000) Coupled leading- and laggingstrand synthesis of mammalian mitochondrial DNA. Cell 100:515-524

9. Gustafsson CM, Falkenberg M, Larsson NG (2016) Maintenance and expression of mammalian mitochondrial DNA. Annu Rev Biochem $85: 133-160$

10. Ricchetti M (2018) Replication stress in mitochondria. Mutat Res 808:93-102

11. Yasukawa T, Kang D (2018) An overview of mammalian mitochondrial DNA replication mechanisms. J Biochem 164:183-193

12. Nicholls TJ, Minczuk M (2014) In D-loop: 40 years of mitochondrial 7S DNA. Exp Gerontol 56:175-181 
13. Kukat C, Wurm CA, Spahr H, Falkenberg M, Larsson NG, Jakobs S (2011) Super-resolution microscopy reveals that mammalian mitochondrial nucleoids have a uniform size and frequently contain a single copy of mtDNA. Proc Natl Acad Sci U S A 108:13534-13539

14. Brown TA, Tkachuk AN, Shtengel G, Kopek BG, Bogenhagen DF, Hess HF, Clayton DA (2011) Superresolution fluorescence imaging of mitochondrial nucleoids reveals their spatial range, limits, and membrane interaction. Mol Cell Biol 31:4994-5010

15. Chatre L, Ricchetti M (2013) Large heterogeneity of mitochondrial DNA transcription and initiation of replication exposed by single-cell imaging. J Cell Sci 126:914-926

16. Chatre L, Ricchetti M (2013) Prevalent coordination of mitochondrial DNA transcription and initiation of replication with the cell cycle. Nucleic Acids Res 41:3068-3078

17. Arena G, Cisse MY, Pyrdziak S, Chatre L, Riscal R, Fuentes M, Arnold JJ, Kastner M, Gayte L, Bertrand-Gaday C, Nay K, AngebaultProuteau C, Murray K, Chabi B, Koechlin-Ramonatxo C, Orsetti B, Vincent C, Casas F, Marine JC, Etienne-Manneville S, Bernex F, Lombes A, Cameron CE, Dubouchaud H, Ricchetti M, Linares LK, Le Cam L (2018) Mitochondrial MDM2 regulates respiratory complex I activity independently of p53. Mol Cell 69:594-609. e8

18. Bajzikova M, Kovarova J, Coelho AR, Boukalova S, Oh S, Rohlenova K, Svec D, Hubackova S, Endaya B, Judasova K, Bezawork-Geleta A, Kluckova K, Chatre L, Zobalova R, Novakova A, Vanova K, Ezrova Z, Maghzal GJ, Magalhaes Novais S, Olsinova M, Krobova L, An YJ, Davidova E, Nahacka Z, Sobol M, Cunha-Oliveira T, Sandoval-Acuna C, Strnad H, Zhang T, Huynh T, Serafim TL, Hozak P, Sardao VA, Koopman WJH, Ricchetti M, Oliveira PJ, Kolar F, Kubista M, Truksa J, Dvorakova-Hortova K, Pacak K, Gurlich R, Stocker R, Zhou Y, Berridge MV, Park S, Dong L, Rohlena J, Neuzil J (2019) Reactivation of dihydroorotate dehydrogenase-driven pyrimidine biosynthesis restores tumor growth of respiration-deficient cancer cells. Cell Metab 29:399-416. e10 
19. Wiehe RS, Gole B, Chatre L, Walther P, Calzia E, Palmer A, Gebhardt JCM, Ricchetti M, Wiesmuller L (2018) Correction: endonuclease G promotes mitochondrial genome cleavage and replication. Oncotarget 9:27908

20. Wiehe RS, Gole B, Chatre L, Walther P, Calzia E, Ricchetti M, Wiesmuller L (2018) Endonuclease G promotes mitochondrial genome cleavage and replication. Oncotarget 9:18309-18326 